Research Report No. 4/2007

\title{
Party Autonomy in the Private International Law of Contracts: Transatlantic Convergence and Economic Efficiency
}

Giesela Ruhl

Follow this and additional works at: http:/ / digitalcommons.osgoode.yorku.ca/clpe

\section{Recommended Citation}

Ruhl, Giesela, "Party Autonomy in the Private International Law of Contracts: Transatlantic Convergence and Economic Efficiency" (2007). Comparative Research in Law \& Political Economy. Research Paper No. 4/2007.

http://digitalcommons.osgoode.yorku.ca/clpe/227 


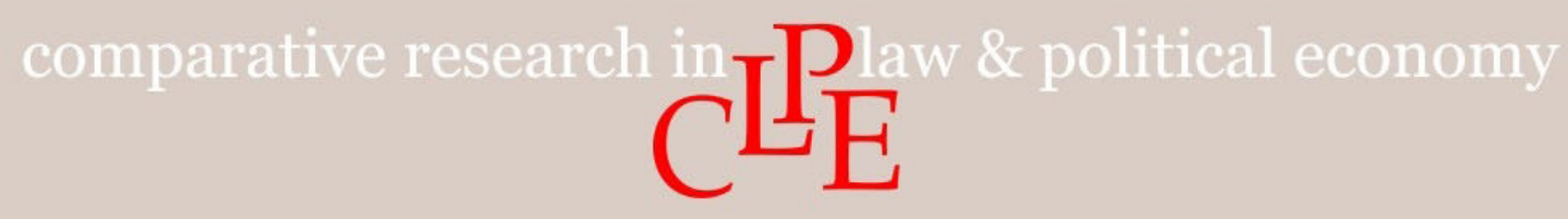

\section{Law Research Institute Research Paper Series}

CLPE Research Paper 4/2007

Vol. 03 No. 01 (2007)

Giesela Rühl

Party Autonomy in the Private International

Law of Contracts: Transatlantic Convergence and Economic Efficiency

Forthcoming in:

CONFLICT OF LAWS IN A GLOBALIZED WORLD

Eckart Gottschalk, Ralf Michaels, Giesela Rühl \& Jan von Hein, eds., Cambridge University Press

Author Contact:

Max Planck Institute for Comparative and Private International Law Mittelweg 187 D-20148 Hamburg, Germany | Email: ruehl@mpipriv.de

This paper can be downloaded without charge from the Social Science Research Network Electronic Library at: http://ssrn.com/abstractid=921842

An index to the working papers in the Comparative Research in Law and Political Economy Research Paper Series is located at: http://www.comparativeresearch.net

CLPE RPS Editors: John Cioffi (University of California at Riverside),

Peer Zumbansen (Osgoode Hall Law School, Toronto, Director,

Comparative Research in Law and Political Economy)

Production Editor: James Brink (Osgoode Hall Law School, Toronto) 

CLPE Research Paper 4/2007

Vol. 03 No. 01 (2007)

\title{
Giesela Rühl
}

\section{Party Autonomy in the Private International LaW of CONTRACTS: Transatlantic CONVERGENCE AND ECONOMIC EFFICIENCY}

\begin{abstract}
It is commonly acknowledged that during the 20th century American and European choice-of-law theory have drifted apart: in the United States the American conflicts revolution swept the traditional vested rights theory out of the courts and the classrooms and gave way to a variety of novel approaches. In Europe, in contrast, legal systems decided to adhere to the classical concept of choice of law invented by Carl Friedrich von Savigny. However, the 20th century has not only seen transatlantic divergence. Almost unnoticed, American and European choice of law theory has developed into the same direction in one area of law: contract law. Both the Restatement (Second) of Conflict of Laws, which today is the most widely followed conflicts regime for contracts in the United States, and the EC Convention on the Law Applicable to Contractual Obligations (Rome Convention), which establishes uniform conflicts rules for virtually all of Western Europe, provide for free party choice of law.
\end{abstract}

This article looks at principle of party autonomy in Europe and the United States in more detail. It demonstrates that the trend of convergence extends beyond basic conceptual similarities and that it reaches business reality through the jurisprudence of American and European courts. However, the article does not confine the discussion of party autonomy to a comparative analysis. It also determines the underlying reasons for the convergence of American and European law by looking at the field from an economic perspective. Two basic questions are addressed: first, what is the economic rationale for granting free party choice of law? Second, can limitations of the free party choice of law such as 
the infringement of public policy, the evasion of mandatory law or the lack of a substantial relationship with the chosen law be justified on economic grounds? In answering these questions the article ventures the hypothesis that the trend of convergence in choice of law can be explained with the help of economic theory.

Keywords: Choice of Law, Conflict of Laws, Private International Law, Party Autonomy, Contract Law, Economic Analysis, Rome Convention, Restatement, UCC

JEL Classification: K12, K33

Author Contact: Giesela Rühl

Max Planck Institute for Comparative and

Private International Law

Mittelweg 187 D-20148

Hamburg, Germany

Email: ruehl@mpipriv.de

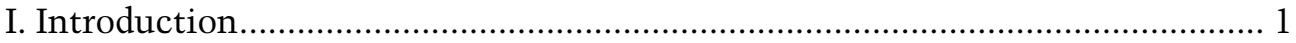

II. The Trend of Convergence: A Comparative Analysis ...................................... 4

A. The Supremacy of Party Autonomy in Europe and the United States ........ 4

B. The Limits to Party Autonomy in Europe and the United States ................ 8

1. Connection to a Foreign Law .................................................................. 9

2. Substantial Relationship to the Chosen Law …..................................... 11

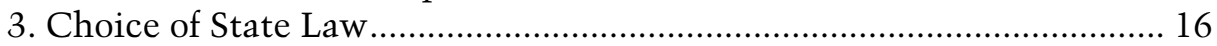

4. Priority of Protective Laws ................................................................... 20

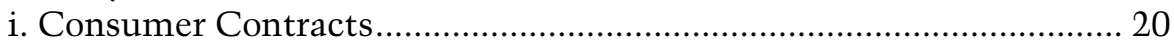

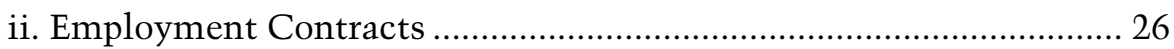

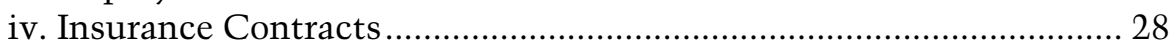

III. The Trend of Convergence: An Economic Explanation................................ 31

A. The Supremacy of Party Autonomy as Victory of Efficiency.................... 32

B. The Limits to Party Autonomy as Expression of Market Failure............... 34

1. Externalities and Third-Party Effects ..................................................... 34

2. Opportunistic Behavior and Information Asymmetry .......................... 37

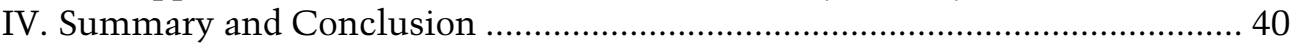




\title{
Party Autonomy in the Private International LaW of CONTRACTS: TransatlantiC CONVERGENCE AND ECONOMIC EFFICIENCY
}

\author{
Giesela Rühl ${ }^{\star}$
}

\section{INTRODUCTION}

It is commonly acknowledged that during the $20^{\text {th }}$ century American and European choice-of-law theory ${ }^{1}$ have drifted apart: In the United States, the American Conflict of Laws Revolution ousted the traditional vested rights theory and paved the way for a variety of novel approaches focusing on flexibility and fairness in individual cases. ${ }^{2}$ In Europe, in contrast, classical choice-of-law theory favoring predictability and legal certainty prevailed. ${ }^{3}$ The $20^{\text {th }}$ century, however, has not only seen transatlantic divergence in choice of law. In fact, after years of vigorous debates legal regimes on either side of the Atlantic have adopted the same approach when it comes to the private international law of contracts. ${ }^{4}$ More specifically, both American and European law

\footnotetext{
Senior Research Fellow at the Max Planck Institute for Comparative and Private International Law, Hamburg, Germany.

${ }^{1}$ In the common law world the provisions that determine the applicable law are usually referred to as choice-of-law rules. In civil law countries, in contrast, the provisions dealing with the applicable law are referred to as the rules of private international law. In the following article I will use both terms interchangeably. See for a discussion of the terminology Eugene F. SCOles, Peter HAY, PATRICK J. BORCHERS \& SYMEON C. SYMEONIDES, CONFLICT OF LAWS $\S 1.1,1-3\left(4^{\text {th }}\right.$ ed. 2004); Symeon C. SymeOnides, Wendy Collins Perdue \& ARTHUR T. vON MEHREN, CONFLICT OF LAWS: AMERICAN, COMPARATIVE, INTERNATIONAL 3 and $6\left(2^{\text {nd }}\right.$ ed. 2003).

${ }^{2}$ Mathias Reimann, Conflict of LaWs in Western Europe - A Guide THROUGH THE JUNGLE 12, 102-05 (1995).

${ }^{3}$ REIMANN, supra note 2 , at 13 .

${ }^{4}$ Friedrich K. Juenger, American and European Conflicts Law, 30 AM. J. ComP. L. 117 (1982); Ole Lando, New American Choice-of-Law Principles and the European Conflict of Laws of Contracts, 30 AM. J. ComP. L. 19 (1982); Mathias
} 
follow the principle of party autonomy and, therefore, allow parties to choose the applicable law.

Of course, the fact that American and European law have moved closer over the last years has not escaped the attention of scholars around the world. ${ }^{5}$ However, up until today the precise extent of transatlantic convergence ${ }^{6}$ is essentially unclear. In fact, nobody has as yet determined how similar the American and the European concepts of party autonomy actually are. And nobody has as yet analyzed how similar the handling of the two concepts is in practice. In this article I fill this gap by analyzing the design and the practical handling of party autonomy in both Europe and the United States. I demonstrate that the trend of convergence extends beyond basic conceptual similarities and that it reaches business reality through the jurisprudence of American and European courts (infra II). However, I do not confine the discussion of party autonomy to a comparative analysis. I also endeavor to relate the comparative insights to the insights of economic theory. More specifically, I analyze the concept of party autonomy from an economic perspective and venture the hypothesis that the trend of

Reimann, Savigny's Triumph? Choice of Law in Contracts Cases at the Close of the Twentieth Century, 39 VA. J. INT'L L. 571, 574 et seq. (1999).

${ }^{5}$ See, e.g., Friedrich K. Juenger, The E.E.C. Convention on the Law Applicable to Contractual Obligations: An American Assessment, in CONTRACT CONFLICTS - THE E.E.C. CONVENTION ON THE LAW APPLICABLE TO CONTRACTUAL Obligations: A COMPARATIVE StUdy 295, 299 (Peter North ed., 1982); Reimann, supra note 4, at 575-78.

${ }^{6}$ In the following I apply a broad definition of "convergence" that describes the general phenomenon of similar solutions in different legal systems irrespective of whether they are brought about by conscious interaction or incidental parallel development. See Hiram E. Chodosh, Comparing Comparisons: In Search of Methodology, 84 IowA L. Rev. 1025, 1118 (1999); Ugo Mattei, Efficiency in Legal Transplants: An Essay in Comparative Law and Economics, 14 INT'L ReV. L. ECON. 3, 6 (1994); UGO MATTEI, COMPARATIVE LAW AND ECONOMICS 126 (1996). See for a comprehensive terminological account JAN VON HEIN, DIE REZEPTION US-AMERIKANISCHEN GESELLSCHAFTSRECHTS IN DEUTSCHLAND $§ 2$ (forthcoming). 
convergence in the context of party autonomy can be explained with the help of economic theory (infra III).

By exploring issues in the private international law of contract from a comparative perspective the article follows the approach Arthur von Mehren applied during his entire academic life. However, the article also follows von Mehren as far as the consideration of economic theory is concerned. This proposition probably comes as a surprise for those who have studied von Mehren's work. After all he never joined the Law \& Economics Movement in the sense that he applied economic theory to legal problems himself. However, his own approach to choice of lawthe so-called "functional analysis" — can be classified as a distant relative of an economic approach to choice of law. This is because it seeks to identify the policies and purposes underlying legal rules and, thus, leaves the confines of doctrinal structures and doctrinal arguments. Just like an economic approach to choice of law von Mehren's "functional analysis" is, therefore, characterized by antidoctrinalism. And even though important conceptual differences remain between his "functional analysis" and an "economic analysis" it is this similarity that makes me believe that applying economic theory to the choice-of-law problem follows von Mehren's approach to law in general and to choice of law in particular. And it is against this background that I hope that this article would have appealed to him.

\footnotetext{
7 See Arthur T. von Mehren \& Donald T. Trautmann, The LaW of Multistate Problems (1965); Arthur T. von Mehren, Choice of Law and the Problem of Justice, 41 LAW \& ConTemp. Problems 27 (1977). See also Arthur T. von Mehren, Special Substantive Rules for Multistate Problems: Their Role and Significance in Contemporary Choice of Law Methodology, 88 HARV. L. ReV. 347 (1974).
} 
[Vol. 03 No. 01

\section{The Trend OF CONVERgence: A COMPARATIVE ANALYSIS}

On both sides of the Atlantic the basic tenet of the private international law of contracts as it stands today is that parties are free to choose the applicable law. In Europe the reign of party autonomy is determined by Article 3 (1) Rome Convention ${ }^{8}$ which has been adopted and implemented in all member states of the European Union. In the United States the principle of free party choice of law flows from Restatement (Second) § 187 and UCC $\S 1-105$. 'However, the supremacy of party autonomy in both the United States and Europe is not a matter of course. Rather, it is the result of a vigorous debate that lasted for many years and ended only some decades ago.

\section{A. The Supremacy of Party Autonomy in Europe AND THE UNITED STATES}

At the beginning of the $20^{\text {th }}$ century, the parties' right to choose the applicable law was a highly disputed issue on either side of the Atlantic. ${ }^{10}$ In Europe, where the Italian scholar Pasquale Stanislao

${ }^{8}$ EC Convention on the law applicable to contractual obligations (consolidated version in 1998 O.J. (C 27) 34 et seq.) [hereinafter Rome Convention].

${ }^{9}$ In February 2001, the National Conference on Commissioners on Uniform State Law has adopted a new Article 1 (General Provisions) including a new UCC § 1301 that is meant to replace UCC $\S 1-105$. However, so far not all states have enacted implementing legislation. And most of the states that have done so did not adopt the new UCC § 1-301 but retained UCC § 1-105. Therefore, crossborder sales within the United States are still for the most part governed by state laws corresponding to $\S 1-105$ UCC. For a detailed account of the criticism of $\S 1-301$ see Jack M. Graves, Party Autonomy in Choice of Commercial Law: The Failure of Revised U.C.C. § 1-301 and a Proposal for Broader Reform, 36 SETON Hall L. ReV. 59 (2005).

${ }^{10}$ See for a more detailed account FRANK VISCHER, INTERNATIONALES VERTRAGSRECHT 29-39 (1962); RAINER MAGOLD, Die PARTEIAUTONOMIE IM INTERNATIONALEN UND INTERLOKALEN VERTRAGSRECHT DER VEREINIGTEN STAATEN VON AMERIKA 49-84 (1987); ANDRÉ ALOYS WICKI, ZUR 
Manicini, had laid the foundation for the modern doctrine of party autonomy during the $19^{\text {th }}$ century, ${ }^{11}$ courts were divided in their attitudes towards freedom of choice. Whereas judges in England, ${ }^{12}$ Germany, ${ }^{13}$ and France ${ }^{14}$ generally tended to favor party autonomy, courts in other states proved to be more hostile. ${ }^{15}$ By the same token, the European academic community was split. While some followed the courts and supported free party choice of law pointing to the concept of individual freedom as well as the virtue of legal certainty ${ }_{1}^{16}$ many prominent conflicts scholars did not allow the

DOGMENGESCHICHTE DER PARTEIAUTONOMIE IM INTERNATIONALEN PRIVATRECHT (1965); Hessel E. Yntema, "Autonomy" in Choice of Law, 1 AM. J. CoMP. L. 341 (1952).

${ }^{11}$ See for a detailed account YUKO NiSHITANI, MANCINI UND DIE PARTEIAUTONOMIE IM INTERNATIONALEN PRIVATRECHT (2000).

${ }^{12}$ See, e.g., In re Missouri Steamship Company (1889) 42 Ch.D. 321, 326; Spurrier v. La Cloche [1902] A.C. 446, 447; Montgomery v. Zarifi [1918] 2 S.L.T. 110, 113; Indian and General Investment Trust, Ltd. v. Borax Consolidated, Ltd. [1920] 1 K.B. 539, 545.

${ }^{13}$ See, e.g., Reichsgericht [RG] [Imperial Court of Justice], Oct. 3, 1923, Entscheidungen des Reichsgerichts in Zivilsachen [RGZ] 108, 241, 243; RG, Jan 27, 1928, RGZ 120, 70, 72.

${ }^{14}$ See, e.g., Cour de Cassation [Supreme Court], Dec. 5, 1910, 39 Clunet 11561158 (1912).

${ }^{15}$ In Switzerland, for example, up until 1952 courts limited the parties' freedom to choose to the rules governing performance of the contract. They did not allow parties to choose the applicable law with regards to the validity of the contract. See, e.g., Schweizerisches Bundesgericht [BG] [Supreme Court], June 9, 1906, Entscheidungen des schweizerischen Bundesgerichts [BGE], BGE 32 II 415, 417; BG, Dec. 14, 1920, BGE 46 II, 490, 493; BG, June 9, 1936, BGE 62 II, 125; BG, June 3, 1947, BGE 73 II, 102, 104-105; BG, Feb. 28, 1950, BGE 76 II, 33, 36.

${ }^{16}$ Neubecker, Das Internationale Privatrecht auf deutschrechtlicher Grundlage, JAHRBUCH FÜR DEN INTERNATIONALEN RECHTSVERKEHR [J. INT. RVERK] 8, 81-83 (1912/13); Ernst Rabel, Rechtsvergleichung und internation ale Rechtsprechung, 1 RABELS ZEITSCHRIFT FÜR AUSLÄNDISCHES UND INTERNATIONALes Privatrecht [RABElsZ] 5, 41 (1927); Gerhard Mayer, Zur Parteiautonomie als Kollisionsnorm, 44 NIEMEYERS ZEITSCHRIFT FÜR INTERNATIONALES RECHT [NIEMZ] 103, 121-39 (1931), GEORG MELCHIOR, DiE GRUNDLAGEN DES DEUTSCHEN INTERNATIONALEN PRIVATRECHTS 498-531 (1932); PAul LeRebours-PigeOnNIÈRe, PréCis De DROIT INTERNATIONAl PRIVÉ 218-23, 
parties to avoid the otherwise applicable law. ${ }^{17}$ They essentially argued that parties could not raise themselves above the law by choosing another. In view of increased international trade, however, the resistance against the free party choice of law melted away in the course of the $20^{\text {th }}$ century. Already in the 1960s, little was left of the former opposition to choice-of-law clauses, and the parties' freedom to choose was generally accepted. The final victory came in 1980 when the principle of party autonomy was incorporated in the Rome Convention.

In the United States, just like in Europe, party autonomy was the focal point of a fierce debate at the beginning of the $20^{\text {th }}$ century. And just like in Europe the divide ran more or less between courts and scholars: While most American courts and especially the Supreme Court recognized a party choice of law, ${ }^{18}$ many scholars were less favorably inclined. ${ }^{19}$ Notably, Joseph $H$. Beale, the Reporter for the Restatement (First), considered the applicable law a matter of state sovereignty and thus beyond the reach of the

368 ( $1^{\text {st }}$ ed. 1928); P. Kayser, L'autonomie de la volonté en droit international privé dans la jurisprudence françaises, 58 CLUNET 32 et seq. (1931); MARCEL Planiol \& GEORGE RIPERT, TRAITÉ, PRATIQUE DE DROIT CIVIL FRANCAIS, VOlUME 6, 37, 639-44 (1930).

${ }^{17}$ See, e.g., MARCEL CALEB, ESSAI SUR LE PRINCIPLE DE L'AUTONOMIE DE LA VOLONTE EN DROIT INTERNATIONAL PRIVE (1927); ERNST FRANKENSTEIN, INTERNATIONALES PRIVATReCHT, VOlume II 158 et seq. (1929); HANS LeWALD, DAS DEUTSCHE INTERNATIONALE PRIVATRECHT AUf GRUNDLAGE DER RECHTSPRECHUNG 199 et seq. (1931); Jean-Pierre Niboyet, La théorie de l'autonomie de la volonté, 16 ReCUEIL DES COURS 5-116 (1927 I).

${ }^{18}$ See, e.g., London Assurance v. Companhia de Moagens do Barreior, 167 U.S. 149, 17 S.Ct. 785, 790 (1897); Mutual Life Insurance Company of New York v. Tine Cohen, 179 U.S. 262, 21 S.Ct. 106, 109 (1900); Pinney v. Nelson, 183 U.S. 144, 22 S.Ct. 52, 54 (1901); Mutual Life Insurance Company of New York v. Hill, 193 U.S. 551, 24 S.Ct. 538, 540 (1904). See also the study of Joseph H. Beale, What Law Governs the Validity of a Contract, 23 HARV. L. ReV. 1 (1909/10).

${ }^{19}$ See, e.g., Beale, supra note 18, at 260-66; RALEIGH C. Minor, CONFLict OF LAWS; OR, PRIVATE INTERNATIONAL LAW 401 (1901). 
parties. ${ }^{20}$ As a result, the Restatement (First) remained silent on the issue, implicitly denying any freedom to choose the applicable law. ${ }^{21}$ However, over the years, the judges' viewpoint held sway. Today, Restatement (Second) § 187 allows for party autonomy and-even though not binding by itself-is followed throughout the United States. Even states that formally still adhere to the Restatement (First) ${ }^{22}$ or apply various forms of interest analysis accept $\S 187$ and the free choice of law as a basic principle of contract conflicts. ${ }^{23}$ As Patrick J. Borchers has pointed out: "... courts of all conflicts stripes have flocked to the Second Restatement's broad endorsement of party autonomy in $\S 187^{\prime \prime} .^{24}$ Just as well, UCC $\S 1-105$ has been adopted in all of the American states.

After many years of discussion party autonomy, thus, has prevailed both in Europe and the United States. It is often termed "a universal approach" ${ }^{25}$ which has also proved to be a success in practice: The majority of international contracts provide for a choice-of-law clause. ${ }^{26}$ And by far the most of these clauses are

\footnotetext{
${ }^{20}$ Joseph H. Beale, A Treatise On the Conflict of Laws, Volume 2, 1079-80 (1935).

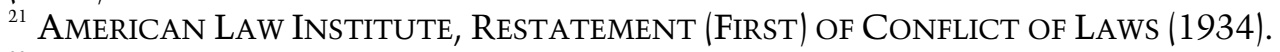

${ }^{22}$ In view of the private international law of contracts these states are Alabama, Florida, Georgia, Kansas, Maryland, New Mexico, Rhode Island, South Carolina, Tennessee, Virginia, and Wyoming. See Symeon C. Symeonides, Choice of Law in the American Courts in 2004: Eighteenth Annual Survey, 52 Am. J. Comp. L. 919, 944 (2004).

${ }^{23}$ Symeon C. Symeonides, The Judicial Acceptance of the Second Conflicts Restatement: A Mixed Blessing 56 MD. L. REV. 1248 (1997). See also Symeon C. Symeonides, Choice of Law in the American Courts in 1996: Tenth Annual Survey, 45 AM. J. Comp. L. 447, 488 (1997).

${ }^{24}$ Patrick J. Borchers, Choice of Law in the American Courts in 1992: Observations and Reflections, 42 AM. J. CoMP. L. 125, 135 (1994).

${ }^{25}$ Borchers, supra note 24, at 135 . See also Russell J. Weintraub, Functional Developments in Choice of Law for Contracts, 187 RECUEIL DES COURS 239, 271 (1984).

${ }^{26}$ See only the most recent annual reports of Symeon C. Symeonides: Choice of Law in the American Courts in 2004, supra note 22, at 967-73; Choice of Law
} 
upheld by the courts when disputes arise. ${ }^{27}$ It is against this background, that party autonomy-today-is not seriously called into question on either side of the Atlantic. That this is so becomes obvious when looking to reform projects in the field: In Europe, the Rome Convention is currently under review and will soon be replaced by a Community Regulation. ${ }^{28}$ However, Article 3 (1) on party autonomy will essentially remain unchanged. By the same token, the latest revision of the UCC that has introduced a new UCC $\S 1-301$ to replace UCC $\S 1-105^{29}$ does not touch upon the parties' right to choose the applicable law.

\section{B. The Limits to PARTy Autonomy in Europe AND THE UNITED STATES}

Beyond the mere fact that party autonomy has emerged as the dominant instrument in the private international law of both Europe and the United States, the two legal systems have moved

in the American Courts in 2003: Seventeenth Annual Survey, 52 Am. J. Comp. L. 9, 51-55 (2004); Choice of Law in the American Courts in 2002: Sixteenth Annual Survey, 51 Am. J. Comp. L. 1, 55-68 (2003); Choice of Law in the American Courts in 2001: Fifteenth Annual Survey, 50 AM. J. Comp. L. 1, 21-40 (2002); Choice of Law in the American Courts in 2000: As the Century Turns, 49 Aм. J. Comp. L. 1, 35-40 (2001); Choice of Law in the American Courts in 1999: One More Year, 48 AM. J. Comp. L. 143, 156-64 (2000); Choice of Law in the American Courts in 1998: Twelfth Annual Survey, 47 AM. J. Comp. L. 327, 384-89 (1999); Choice of Law in the American Courts in 1997, 46 AM. J. Comp. L. 233, 273-76 (1998); Choice of Law in the American Courts in 1996, supra note 23, at 488-90; Choice of Law in the American Courts in 1994: A View "From the Trenches", 43 AM. J. Comp. L. 1, 54-72 (1995); Choice of Law in the American Courts in 1993 (and in the Six Previous Years), 42 AM. J. COMP. L. 599, 642-43 (1994).

${ }^{27}$ Ibid. According to a recent study involving 697 American cases, choice-of-law clauses are enforced in $85 \%$ of the cases. See Larry Ribstein, From Efficiency to Politics in Contractual Choice of Law, 37 GA. L. Rev. 363, 374-75 (2003).

${ }^{28}$ See the European Commission's Proposal of the European Parliament and the Council for a Regulation on the law applicable to contractual obligations of 15 December 2005, COM(2005) 650 final [hereinafter Proposal for a Rom-I Regulation].

${ }^{29}$ See supra note 9. 
closer in view of other features as well. Most importantly, both do not grant party autonomy unlimited. In fact, both under the Rome Convention and under the Restatement (Second) as well as under the UCC a number of restrictions on the freedom of choice are in place. And even though not all restrictions look the same under the respective provisions, a closer analysis proves that their application and interpretation over the last years has often led to rather similar results in practice.

\section{CONNECTION TO A FOREIGN LAW}

A first limitation to party autonomy that has surfaced on both sides of the Atlantic during the $20^{\text {th }}$ century relates to choice-oflaw clauses in purely domestic cases: According to Article 3 (3) Rome Convention a choice of a foreign law, whether or not accompanied by the choice of a foreign tribunal, does not, where all other elements relevant to the contract at the time of the choice are connected with one country only, prejudice the application of the mandatory laws of that country. In purely domestic cases a choice-of-law clause, therefore, will not be enforced in view of the mandatory provisions of the law which would be applicable had the parties not agreed on a foreign law. The Restatement (Second) and the UCC do not contain an express provision that corresponds to Article 3 (3) Rome Convention. This, however, does not mean that the parties may derogate from the mandatory provisions of the law otherwise applicable even if there is no connection to a foreign state: The commentary to Restatement (Second) $\S 187$ states that the provision does only apply "when two or more states have an interest in the determination of the particular issue". ${ }^{30}$ Therefore, it is not applicable "when all contacts are located in a single state and when, as a consequence, there is only one interested state" ${ }^{31}$ That this statement has not only theoretical but also practical meaning becomes obvious when looking at the cases rendered under

\footnotetext{
${ }^{30}$ Restatement (Second) $§ 187, \mathrm{cmt}$. d).

${ }^{31}$ Restatement (Second) § 187, cmt. d).
} 
Restatement (Second) $§ 187$ as well as under UCC § 1-105 (1): All cases decided under any of the two provisions during the last couple of years touch upon the legal systems of at least two states. $^{32}$

However, more relevant than the mere fact that both American and European law restrict the free party choice of law in purely domestic cases is the question what exactly is considered to be a domestic case under both legal regimes. In other words: What amounts to a sufficient relationship to a foreign law? Which elements turn a domestic case into an international case? A look at the relevant case law shows that courts in both Europe and the United States do not require much in order to assume a connection to a foreign country. It is usually regarded as sufficient if one of the parties is habitually resident abroad, if one of the parties is incorporated abroad, if one of the parties has her principle of business abroad, if the contract was entered abroad, or if performance is to take place abroad. ${ }^{33}$ This holds true even if all but one element are connected with one country only. ${ }^{34}$ As a result, it is fair to say that both American and European law do not only require a sufficient relationship to a foreign law but also find such a relationship in essentially the same cases. However, it is also fair to say that the threshold for finding a sufficient relationship is rather low on both sides of the Atlantic. Therefore,

\footnotetext{
${ }^{32}$ See the cases cited in SCOLES, HAY, BORCHERS \& SYMEONIDES, supra note 1, $\S 18$, at 946-87.

${ }^{33}$ See, for Article 3 (3) of the Rome Convention Dieter Martiny, Deutsches Internationales Privatrecht, in INTERNATIONALES VERTRAGSRECHT 59, 71-72, no. 62 (Christoph Reithmann \& Dieter Martiny eds., $6^{\text {th }}$ ed. 2004). See for Restatement (Second) 187 and UCC $\S 1-105$ the cases cited in SCOLES, HAY, BORCHERS \& SYMEONIDES, supra note $1, \S 18$, at 946-87.

${ }^{34}$ See Richard Plender \& Michael Wilderspin, The European Contracts CONVENTION no. 5-24, 105 (2001) and F.M.B. Reynolds, Vita Food Resurgent, 108 L.Q.R. 395 (1992). Both refer to the case of Svolmar Shipping Co. Ltd. v. Hellenic Steel Co. („,The Komnino S“) [1991] Llyod's Rep. 370 which, however, was decided under the English common law rules.
} 
the limitation relating to purely domestic cases does not amount to a major obstacle to a free choice of law in practice. ${ }^{35}$

\section{Substantial ReLATIONSHIP TO THE CHOSEN LAW}

In addition to limiting the free party choice of law in purely domestic cases, American law imposes further restrictions on party autonomy where the choice of law touches upon the mandatory provisions of the law otherwise applicable to the transaction: According to Restatement (Second) $\S 187$ (2) (a) and UCC $\S 1-105$ (1) the law of the state chosen by the parties will only be applied if the chosen state has a substantial relationship to the parties or the transaction. A choice-of-law clause, thus, will not be enforced against the mandatory provisions of the law otherwise applicable if there is a lack of a substantial relationship between the contract and the chosen law. The Rome Convention, in contrast, does not require a substantial or other relationship to the chosen law. ${ }^{36}$ As long as the contract is connected with more than one country in the meaning of Article 3 (3) a choice-of-law clause will be enforced. ${ }^{37}$ The Rome Convention, therefore,

\footnotetext{
${ }^{35}$ Note, however, the case of Prows v. Pinpoint Retail Systems, Inc. 868 P.2d 809 (Utah 1993), in which the Supreme Court of Utah - wrongfully - limited the analysis to the question whether there was a connection to more than one American state thereby neglecting that the Restatement (Second) applies to national and international cases.

${ }^{36}$ Plender \& WilderspiN, supra note 34 , no. 5-25, at 105-106.

${ }^{37}$ See, for example, the infamous German Gran Canaria Timeshare cases in which the plaintiffs were German nationals and resident in Germany who had, while on holiday in Spain, signed onerous timeshare contracts relating to property situated in Spain. The choice-of-law clause in these contracts provided for application of the law of the Isle of Man which had a connection to the transaction only insofar as the Time Share sellers were companies registered in the Isle of Man. This connection, however, was rather weak since the contracts were to be performed the Time Share sellers' German subsidiaries. See Bundesgerichtshof [BGH] [Federal Court of Justice], Mar. 19, 1997, DIE DEUTSCHE RECHTSPRECHUNG AUF DEM GEBIET DES INTERNATIONALEN PRIVATRECHTS [IPRSPR.] 1997, no.34.
} 
imposes less strict requirements for the enforcement of choice-oflaw clauses than the Restatement (Second) as well as the UCC. ${ }^{38}$

In practice, however, the differences between the two conflicts regimes have turned out to be minor during the last years. Several factors are responsible for this finding: First of all, under Restatement (Second) $\S 187$ (2) (a) the absence of a substantial relationship to the chosen law can be cured by the presence of another reasonable basis for the parties' choice. A reasonable basis in this sense exists, for example, where the parties conclude and perform the contract in countries whose law is or whose law is relatively undeveloped. ${ }^{39}$ But there are other situations in which the parties have good reasons to provide for application of a foreign law. In fact, there are few situations in which the parties do not have a good reason for a choice of law. ${ }^{40}$ As the commentary to Restatement (Second) $§ 187$ (2) (a) points out: Parties enter into contracts for serious purposes and usually do not provide for choice-of-law clause "in the spirit of adventure" or to provide "mental exercise for the judge". ${ }^{41}$ Second, and more importantly, courts in the United States have lowered the requirements that need to be met in order to find a substantial relationship to the chosen law. Today, a sufficient substantial relationship is, for example, assumed when the parties choose the law of the state

\footnotetext{
${ }^{38}$ See also Patrick J. Borchers, The Internationalization of Contractual Conflicts Law 28 VAND. J. TRANSNAT'L L. 421, 434 (1995); Reimann, supra note 4, at 578.

${ }^{39}$ Restatement (Second) § 187, cmt. f).

${ }^{40}$ As one commentator has noted: "It is not clear why any choice the parties mutually agree to is not prima facie 'reasonable'." See Larry E. Ribstein, Choosing Law by Contract, 18 J. CORP. L. 245, 264 (1993).

${ }^{41}$ Restatement (Second) § 187, cmt. f). See, e.g., Radioactive, J.V. v. Manson, 153 F. Supp. 2d 462 (S.D.N.Y: 2001). The case revolved around a music recording contract containing a New York choice-of-law clause. The court noted that New York had sufficient contracts with the contract. However, it also held that even in the absence of such contacts, the choice of New York law would have been reasonable: "New York federal and state courts have significant experience with music industry contracts, and the parties wanted to avail themselves of that experience by selecting a New York forum and New York law." Id. at 471.
} 
where the contract was made, ${ }^{42}$ where performance of the contract is to take place, ${ }^{43}$ where one of the parties is domiciled, ${ }^{44}$ where one of the parties is incorporated ${ }^{45}$ or where one of the parties has her principal place of business. ${ }^{46}$ However, any other relationship to a foreign state, however small, will also suffice. In Evans v. Harry Robinson Pontiac-Buick, Inc., ${ }^{47}$ for example, the Supreme Court of Arkansas upheld a choice of Texas law relating to a retail installment agreement entered into in Arkansas between an Arkansas buyer and an Arkansas car dealer on the face that the contract had been assigned to a Texas finance company. The court found that this assignment in combination with the buyer's knowledge of it established a sufficient relationship with Texas so as to justify the application of Texas law to the retail installment agreement. ${ }^{48}$ Just as well, the Supreme Court of Massachusetts

${ }^{42}$ Restatement (Second) $\S 187, \mathrm{cmt}$. f).

${ }^{43}$ Restatement (Second) $\S 187$, cmt. f).

${ }^{44}$ Restatement (Second) $§ 187, \mathrm{cmt}$. f). See, e.g., Ticknor v. Choice Hotels Int'1 Inc. 265 F.3d 931 ( $9^{\text {th }}$ Cir. 2001); Johnson v. Ventra Group, Inc. 191 F.3d $732\left(6^{\text {th }}\right.$ Cir, 1999); International Business Machines Corporation v. Bajorek 191 F.3d 1033 (9 ${ }^{\text {th }}$ Cir. 1999).

${ }^{45}$ See, e.g., Ciena Corporation v. Jarrard, 203 F.3d 312, $324\left(4^{\text {th }}\right.$ Cir. 2000); Dopp v. Teachers Insurance and Annuity Association, 1993 WL 404076 (S.D.N.Y. 1993); Nedlloyd Lines B.V. v. Superior Court 3 Cal. $4^{\text {th }} 459,467$ (1992). But see Curtis 1000, Inc. v. Suess 24 F.3d 941, 948 ( $7^{\text {th }}$ Cir. 1994) (refusing the enforcement of a Delaware choice-of-law clause for lack of a substantial relationship with that state even though one of the parties was incorporated in Delaware); Triad Fin. Establishment v. Tumpane, 611 F.Supp 157, 163-164 (1985) (refusing the enforcement a New York choice-of-law clause in a marketing agreement between a Liechtenstein company and a New York corporation with main office in Washington and only two employees in New York).

${ }^{46}$ Restatement (Second) § 187, cmt. f). See, e.g., A.G. Edwards \& Sons. Inc. v. Smith 736 F.Supp. 1030, 1036 (D.Ariz. 1989); Long v. Holland American Law Westours, Inc. 26 P.3d 430 (Alaska 2001).

${ }^{47} 336$ Ark. 155, 983 S.W.2d 946 (1999).

${ }^{48}$ See also the pre-Restatement case Hellenic Lines, Ltd. v. Embassy of Pakistan, 307 F.Supp. 947 (S.D.N.Y. 1969) (upholding a choice of English law in a contract for the shipping of goods from Pakistan to the United States on a Greek vessel without further discussion). 
upheld a Massachusetts choice of law in Hodas v. Morin. ${ }^{49}$ The case revolved around a contract for surrogate motherhood between a Connecticut couple and a New York woman. According to the gestational carrier agreement all steps necessary to carry out the contract, including implantation and prenatal care were to take place in Connecticut. Yet, when the genetic parents brought an action for pre-birth judgments of parentage and for issuance of a pre-birth record of birth the court upheld the Massachusetts choice of law. It argued that Massachusetts had a substantial relationship to the transaction because the contract envisaged delivery of the child in a hospital in Massachusetts.

Against this background, it seems that American courts consider almost any relationship to the foreign law as a substantial relationship in the meaning of $\S 187$ (2) (a) Restatement and thus reduce the number of cases in which a choice-of-law clause will not be enforced against the mandatory provisions of the law otherwise applicable. Actually, during the last years in the United States only few choice-of-law clauses relating to a contract have not been enforced for lack of a substantial relationship under Restatement (Second) $\S 187$ (2) (a) or UCC $\S 1-105 .{ }^{50}$ Compared to the number of cases in which the courts have upheld choice-of-law clauses despite partly negligible contacts to the chosen law, the number of cases invalidating choice-of-law clauses for insufficient

\footnotetext{
${ }^{49} 814$ N.E.2d 320 (Mass. 2004).

${ }^{50}$ Sentinel Industrial Contracting Corp. v. Kimmins Industrial Service Corp., 743 S.2d 954 (Miss. 1999) (refusing the enforcement of a Texas choice-of-law in a contract that provided for the dismantlement of an Exxon ammonia plant located in Mississippi and for its shipment and reassembly in Pakistan); United Countries Trust Company v. Mac Lum, Inc, 643 F. 2d 1140 (5 ${ }^{\text {th }}$ Cir. 1981) (refusing the enforcement of a New York choice of law in a sale-and-lease-back contract between a Kentucky and a New Jersey corporation concerning restaurant fixtures and equipment located in Georgia). See also Curtis 1000, Inc. v. Suess, supra note 45; Triad Fin. Establishment v. Tumpane, supra note 45; CCR Data Systems, Inc. v. Panasonic Communications \& Systems Company, 1995 WL 54380 (D.N.H., 1995); LaGuardia Associates v. Holiday Hospitality Franchising, Inc., 92 F.Supp.2d 119 (E.D.N.Y. 2000).
} 
relationship to the chosen law is so small that they must be deemed exceptions. ${ }^{51}$ They certainly cannot impair the general impression that the substantial relationship requirement embodied in Restatement (Second) § 187 (2) (b) and UCC § 1-105 does not play a significant role in practice and that, as a result thereof, the United States are moving closer to Europe.

That American and European law are moving closer becomes also obvious when looking at recent legislative developments in the field: To begin with, several American states have eased the choice of an unrelated law. Oregon and Louisiana, for example, have enacted legislation that does not require any connection to the chosen law. ${ }^{52}$ Additionally, Texas has enacted a provision that allows a choice of law for transactions involving not less than U.S. $\$ 1,000,000.00$ regardless of whether the transaction bears a reasonable relation to that jurisdiction. ${ }^{53}$ By the same token, California, Illinois and New York allow for a free choice of their own law without any further requirements as long as the transaction in question covers in the aggregate not less than U.S. \$250,000.00. ${ }^{54}$ However, more important than these developments on the state level is that the substantial relationship requirement has recently been abandoned by both the new UCC § 1-301 and UCITA $\S 109(\mathrm{a}) .{ }^{55}$ If both acts are implemented by the American

${ }^{51}$ See also William J. Woodward, Contractual Choice of Law: Legislative Choice in an Era of Party Autonomy, 54 SMU L. REV. 697, 716 (2001).

${ }^{52}$ Louisiana Civil Code Art. 3540; Oregon Revised Statutes $§ 81.120$.

${ }^{53}$ Texas Business \& Commerce Code $\S 35.51$ (c). See for a detailed discussion Cindy G. Buys, The Arbitrators' Duty to Respect the Parties' Choice of Law in Commercial Arbitration, 79 St. John's L. Rev. 59, 82-89 (2005); Edith Friedler, Party Autonomy Revisited: A Statutory Solution to a Choice-of-Law Problem, 36 J. MARShall L. ReV. 471 (1989).

${ }^{54}$ New York General Obligations Law $\S 5-1401 ; 735$ Illinois Compiled Statute 105/5-5; California Civil Code $\S 1646.5$.

${ }^{55}$ However, according to the new UCC $\S 1-301$ (e) (1) a reasonable relation is required if one of the parties is a consumer. 
states $^{56}$ they will further the apparent convergence of European and American law.

\section{CHOice of STATE LAW}

The third limitation that has emerged in both the United States and Europe relates to the subject matter of choice-of-law clauses: While both legal systems allow the parties to choose the law of a state, they do not recognize the choice of general principles of law or non-state codifications. In Europe, this finding flows from the wording of the Rome Convention which leaves no doubt that its conflicts rules only refer to state laws. ${ }^{57}$ Article 1 (1) expressly stipulates that the Convention governs the "choice between the laws of different countries". Furthermore, all other provisions, especially those dealing with contracts, such as Article $3(3)$ and 7 (1) refer to the applicable law as "the law of a country". In the United States, in contrast, the situation is not as clear. In fact, the issue is not even very much discussed. ${ }^{58}$ However, the most important provisions in the field, namely Restatement (Second) § 187 , UCC § 1-105 and the new UCC § 1-301, designate the law to which reference is made as the "law of a state". And since "state" is defined in Restatement (Second) $\S 3$ as "territorial unit with a

\footnotetext{
${ }^{56}$ So far the UCITA has been implemented by two states, Maryland and Virginia. More states are bound to follow. The new UCC $\S 1$-301, in contrast, has not yet been adopted on a large scale. Most states that have implemented the revised version of Article 1 have retained UCC $\S 1$ 1-105. See, e.g., Alabama Code § 7-1-301; Arkansas Code Ann. § 4-1-301; Minnesota Statutes Ann. $\S 336,1.301$; Virginia Code Ann. § 8.1A-301 (b), and supra note 9.

${ }^{57}$ LAWrenCE COlLiNs et al., DiCEY AND MORRIS ON THE CONFLICT OF LAWS no. 32-079, 1223 (13 ${ }^{\text {th }}$ ed. 2000); Paul Lagarde, Le nouveau droit international privé des contrats après l'entrée en vigeur de la convention de Rome du 19 juin 1980, 80 REV. CRIT. DR. INTERNAT. PRIVÉ 287, 300-01 (1991); Ulrich Drobnig, The UNIDROIT Principles in the Conflict of Laws, UNIFORM LAW REVIEW 385, 388 (1998); Ralf Michaels, Privatautonomie und Privatkodifikation, 62 RABELsZ 580, 593-94 (1998); Peter North \& J.J. FAWCETt, Cheshire AND NORTH'S PRIVATE INTERNATIONAL LAW 559-60 (13 ${ }^{\text {th }}$ ed. 1999).

${ }^{58}$ See only Symeon C. Symeonides, Contracts Subject to Non-State Norms, 54 AM. J. COMP. L. 209 (2006).
} 
distinct body of law" this wording suggests that only the application - and the choice-of state law is contemplated. Case law supports this finding: In Trans Meridian Trading Inc. v. Empresa Nacional de Comerzialicion de Insumos, for example, the Court of Appeal for the $9^{\text {th }}$ Circuit refused to enjoin payment on an international letter of credit despite the fact that the contract had been expressly made "subject to the Uniform Customs and Practice for Documentary Credit (1983 Revision) International Chamber of Commerce (Publication no. 400)" (UCP) which allowed issuance of an injunction under the given circumstances. The court argued that the UCP was not the law "of a foreign jurisdiction, but rather ... a compendium of commercial practices published by the International Chamber of Commerce". Therefore, "a provision in a letter of credit that the UCP governs the transaction" did not "prevent application of California's Commercial Code" ${ }^{\prime 59}$

Against this background, it is fair to say that-at least in practice-not only European but also American law excludes the choice of a non-state body of law. However, despite this finding two remarks are in order: First, the fact that a choice of non-state rules is not allowed under both legal systems does not mean that such a choice is ignored all together. ${ }^{60}$ To the contrary: In both Europe and the United States a choice of non-state rules is given effect with the help of the doctrine of incorporation, which allows the parties, in the exercise and within the limits of freedom of contract, to incorporate such rules as terms of the contract. ${ }^{61}$ The comment to Restatement (Second) $§ 187$ expressly notes: "The

\footnotetext{
${ }^{59} 829$ F.2d 949, 953-54 (9 ${ }^{\text {th }}$ Cir. 1987) confirming Pubali Bank v. City National Bank et al. 777 F.2d 1340, 1343 (9 ${ }^{\text {th }}$ Cir. 1985). See also P. John Kozyris, Choice of Law in the American Courts in 1987: An Overview, 36 AM. J. Comp. L. 547, 561 (1988).

${ }^{60}$ See also Ralf Michaels, The Re-State-Ment of Non-State Law: The State, Choice of Law, and the Challenge from Global Legal Pluralism, 51 WAYNE L. REV. 1209, 1231-33 (2005); Symeonides, supra note 58, at 215-21.

${ }^{61}$ Drobnig, supra note 57, at 386; Lagarde, supra note 57, at 300-01; Michaels, supra note 57, at 595-96; Symeonides, supra note 58, at 216-17 (2006).
} 
parties, generally speaking, have power to determine the terms of their contractual engagement. They may spell out these terms in the contract. In the alternative, they may incorporate into the contract by reference extrinsic material which, among other things, may be the provisions of some foreign law." ${ }^{162}$ The reporter's note to the Restatement (Second) $\S 187$ adds "that the parties may also stipulate for the application of trade association rules or well known commercial customs. ${ }^{\prime \prime 3}$ And the comment to the new UCC § 1-302 emphasizes that the parties may depart from the variable provisions of the UCC "by stating that their relationship will be governed by recognized bodies of rules or principles applicable to commercial transactions ${ }^{\prime \prime} .^{64}$ As examples for such bodies of rules or principles the comment refers to "those that are promulgated by intergovernmental authorities such as UNCITRAL or UNIDROIT (see, e.g., Unidroit Principles of International Commercial Contracts), or non-legal codes such as trade codes" ${ }^{65}$

${ }^{62}$ Restatement (Second) $\S 187, \mathrm{cmt}$. c). By the same token, comment 1 to UCC $\S 1-105$ provides that "an agreement as to choice of law may sometimes take effect as shorthand expression of the intent of the parties as to matters governed by their agreement."

${ }^{63}$ Restatement (Second) § 187, Reporter's Note to subsection 1 quoting London Assurance v. Companhia de Moagens, 167 U.S. 149 (1887) (dealing with average adjustment according to usages of Lloyds); Boole v. Union Marine Insurance Company, 52 Cal. App. 207, 198 Pac. 416 (1921) (dealing with adjustment of loss according to English law and customs).

${ }^{64}$ UCC § 1-302, cmt. 2 (2001 Revision).

${ }^{65}$ UCC $\S 1-302$, cmt. 2 (2001 Revision). This general principle is reiterated in other parts of the UCC such as Article 5 which regulates letters of credit. According to the new version of UCC $\S 5-116$ (c) parties are expressly allowed to make a letter of credit subject to any rules of custom or practice such as the UCP. If the parties avail themselves of this option "those rules will govern" except to the extent of any conflict with the non-variable provisions of the UCC. Since § 5-116 UCC has been adopted by all American states with the exception of Wisconsin the Trans Meridian Trading case came out differently today. It would have come out differently even back then if the law of New York had been applicable: according to N.Y. UCC § 5-102 (4) former Article 5 UCC did not apply if any portion of a letter of credit was subject to the UCP. In 
Second, even though European and American law do not honor a choice of a non-state body of law at present it seems that attitudes on both sides of the Atlantic are in the process of changing: To begin with, two American states, Oregon and Louisiana, have recently adopted choice-of-law statutes that effectively abandon any limitation in this context. More specifically they have enacted provisions that expressly allow the parties to choose the governing "law" rather than the "law of a state" ${ }^{.6}$ That this is meant to broaden the parties' choice as compared to the Restatement (Second) or the UCC becomes obvious when looking to the official comments to the Oregon codification: There, it is emphasized that "parties to an international contract may choose to have it governed by the Unidroit Principles of International Commercial Contracts. ${ }^{167}$ But not only in the United States the resistance towards the choice of non-state laws seems to melt away: In Europe, Article 3 (2) of the recently submitted Proposal for a Rom-I Regulation ${ }^{68}$ provides that the parties shall be allowed to "choose as the applicable law the principles and rules recognised internationally or in the Community". According to the accompanying explanatory memorandum, this wording is meant to "authorise the choice of the UNIDROIT Principles, the European Principles of Contract Law or a possible future Community instrument, while excluding the lex mercatoria, which is not precise enough, or private codifications not

the meanwhile New York has adopted § 5-116 (c) UCC without any nonuniform amendments. See also UNIFORM COMMERCIAL CODE (U.L.A.), § 5-116, no. 181-83 (2002); Dellas W. Lee, Letters of Credit: What does Revised Article 5 have to offer to Issuers, Applicants, and Beneficiaries? 101 CoM. L. J. 234, 23941 (1996).

${ }^{66}$ Louisiana Civil Code Art. 3540; Oregon Revised Statutes $\S 81.120$. See for a detailed discussion of the Oregon statute, James A. R. Nafziger, Oregon's Conflicts Law Applicable to Contracts, 38 WillameTte L. ReV. 397-413 (2002); Symeon C. Symeonides, Codifying Choice of Law for Contracts: The Oregon Experience, 67 RABELSZ 726-47 (2003).

${ }^{67}$ Oregon Revised Statute $\S 81.120$, cmt. 3 printed in 38 WillameTte L. ReV. 419 (2002).

${ }^{68}$ See supra note 28. 
adequately recognized by the international community ${ }^{\prime 6} .{ }^{69} \mathrm{It}$, therefore, seems that both in the United States and Europe the view that parties should be allowed to choose a non-state body of law is gaining ground.

\section{Priority of Protective LaWs}

Next to the aforementioned limitations of party autonomy which impose requirements for the validity and enforceability of a free party choice of law, both American and European law restrict choice-of-law clauses when it comes to certain contracts. These restrictions usually refer to contracts in which one party is perceived to be systematically in a weaker position, most importantly consumer contracts, employment contracts and insurance contracts. $^{70}$ However, whereas in Europe these limitations are expressly laid down in the Rome Convention orin the case of insurance contracts-in other Community acts, courts in the United States had to develop the applicable principles over a period of several years on a case-by-case basis.

\section{i. Consumer Contracts}

The most important transactions for which both American and European law significantly curtail the possibility of a free party choice of law are consumer transactions, i.e. transactions in which one party is a natural person acting outside his trade or profession. In Europe, Article 5 (2) Rome Convention provides that a choiceof-law clause in such contracts must not deprive the consumer of

\footnotetext{
${ }^{69}$ See Explanatory Memorandum, supra note 28, at 5.

${ }^{70}$ Additionally, in the United States choice-of-law clauses are given limited effect in franchise contracts. See, e.g., Twin Cities Galleries, LLC v. Media Arts Group, Inc., 2006 WL 334908 (D. Minn.); Modern Computer Systems, Inc. v. Modern Banking Systems, Inc., 858 F.2d 1339 (8th Cir. 1988); Wright-Moore Corporation v. Ricoh Corporation, 908 F.2d 128 (7th Cir. 1990); Tele-Save Merchandising Co. v. Consumers Distributing Company, Ltd., 814 F.2d 1120 (6th Cir. 1987). See also SCOLES, HAY, BORCHERS \& SYMEONIDES, supra note 1, $\S 18.5$, at 966-974.
} 
the protection afforded to him by the mandatory rules of the law of the country in which he has his habitual residence if the contract has been concluded under certain circumstances. ${ }^{71}$ As a result, a choice of law cannot strip the consumer of the coverage of the consumer protection laws of his habitual residence. Instead, he may rely on the mandatory rules of his habitual residence and, thus, invoke the law whichever is the more favorable to him. ${ }^{72}$

In the United States, in contrast, the effect of choice-of-law clauses in consumer contracts is not expressly limited. Neither the Restatement (Second) nor the UCC contain any provision to this extent. Nonetheless, over the years American courts have found a means to protect consumers against choice-of-law clauses: the fundamental public policy doctrine laid down in Restatement (Second) $\S 187(2)(\mathrm{b}) .^{73}$ According to this doctrine a choice-of-law clause is not effective to the extent that application of the law of the state or country designated would be contrary to a fundamental policy of the state or country which has a materially greater interest than the chosen state in the determination of the particular issue and which, under $\S 188$, would be the state of the applicable law in the absence of an effective choice of law by the

${ }^{71}$ More specifically, Article 5 (2) applies (i) if in the country of the consumer's habitual residence the conclusion of the contract was preceded by a specific invitation addressed to the consumer or by advertising, and the consumer took all the steps necessary on his part for the conclusion of the contract in that country, or (ii) if the other party or his agent received the consumer's order in that country, or (iii) if the consumer travelled from that country to another country and there gave his order, provided that the consumer's journey was arranged by the seller for the purpose of inducing the consumer to buy.

${ }^{72}$ C.G.J. Morse, The EEC Convention on the Law Applicable to Contractual Obligations 2 YBK. E.L. 107, 136-137 (1982); PLENDER \& WILDERSPIN, supra note 34 , no. 7-21, at 140 .

${ }^{73}$ UCC $\S 1-105$ (1) does not contain an express fundamental policy exemption. However, it has been held that the public policy limitation has to be read into the provision. See Mell v. Goodbody \& Co., 295 N.E.2d 97, 100 (Ill. App. 1973). See SCOlES, HAY, BORCHERS \& SYMEONIDES, supra note $1, \S 18.12$, at 985-986; Röhm \& Koch, Choice of Law in International Distribution Contracts: Obstacle or Opportunity, 11 N.Y. INT'L L. Rev. 1, 7 (1998). 
parties. ${ }^{74}$ Of course, the concept of fundamental public policy is highly indeterminate. The commentary to Restatement (Second) $\S$ 187 (2) (b) even acknowledges that "no detailed statement can be made of the situations where a 'fundamental' policy of the state of the otherwise applicable law will be found to exist". However, it points out that a fundamental policy "may be embodied in a statute ... which is designed to protect a person against the oppressive use of superior bargaining power ${ }^{\prime \prime}{ }^{75}$ Since consumer contracts are regarded as one of the prime examples for contracts in which the parties are in unequal bargaining positions, American courts tend to invalidate choice-of-law clauses in consumer contracts for violation of public policy. More specifically, they tend to invalidate choice-of-law clauses in consumer contracts that call for application of a law other than the law of the consumer's habitual residence the main argument being that this would be the law otherwise applicable under $\S 188$ Restatement (Second). ${ }^{76}$ They do so especially in cases where the consumer protection schemes of the law of the consumer's habitual residence either exclude any choice of law ${ }^{77}$ or prohibit any express or implied waiver. ${ }^{78}$ In America Online, Inc. v. Superior Court, ${ }^{79}$ for example, the court did not enforce a Virginia choice-of-law

\footnotetext{
${ }^{74}$ A noteworthy statutory exception to the public policy doctrine is housed in the Texas Business \& Commerce Code: According to $\S 35.51$ (b) a choice of law clauses will be enforced even where that choice contravenes a fundamental public policy of another state.

${ }^{75}$ Restatement (Second) $\S 187, \mathrm{cmt}$. g). See for a detailed discussion of this interpretation of the public policy exception Tele-Save Merchandising Co. v. Consumers Distributor Corporation, 814 F.2d 1120, 1123 (6th Cir. 1987); Wallace Hardware Company, Inc. v. Abrams 223 F.3d 382, 399 (6th Cir. 1999)

${ }^{76}$ There are also cases that invalidate a choice-of-law clause in consumer contracts for violation of a fundamental public policy of a third country. See, e.g., Long v. Holland American Law Westours, Inc. 26 P.3d 430 (Alaska 2001).

${ }^{77}$ Express exclusions are to be found, for example, in Louisiana and Oregon. See Louisiana Revised Statutes § 51:1418 C (1); Oregon Revised Statutes § 81.105. ${ }^{78}$ See, e.g., America Online, Inc. v. Superior Court, 108 Ca. Rptr.2d 699 (Calif. App. 2001); Stone Street Services, Inc. v. Daniels, 2000 WL 1909373 (E.D.Pa. 2000).

${ }^{79} 108$ Ca. Rptr.2d 699 (Calif. App. 2001).
} 
clause in a contract for internet services between America Online and California consumers because California had a consumer protection statute providing that any waiver of the consumer's rights under the statute was void as contrary to California public policy. The consumers filed a class action against America Online charging that the defendant continued to debit their credit cards after the consumers terminated their subscription. The court held that enforcement of the choice-of-law clause would be the functional equivalent of a contractual waiver of the consumer protection provisions of the California statute and held the clause unenforceable. ${ }^{80}$ Just as well, the Supreme Court of Pennsylvania refused to enforce a Pennsylvania choice-of-law clause in Stone Street Services, Inc. v. Daniels. ${ }^{81}$ The case revolved around an annuity agreement sold by a Pennsylvania corporation to a Kansas consumer who had suffered mental injury as a result of an accident. A Kansas statute prohibited a party from "tak[ing] advantage of the inability of the consumer reasonably to protect the consumer's interest because of the consumer's physical infirmity, ignorance, illiteracy, inability to understand the language of the agreement or similar fact ${ }^{\prime \prime}{ }^{82}$ Additionally, the statute prohibited waiver of its provisions. The court held that Pennsylvania law should not be applied because it would violate Kansas fundamental policy embodied in the statute.

As a result of the American case law, consumers in the United States are usually afforded the protection of the law of the habitual residence and thus the same protection as in Europe. Differences seem to remain only insofar as the public policy doctrine of the Restatement (Second) invalidates a choice of law altogether whereas Article 5 of the Rome Convention allows a choice of law but calls for application of the law of the consumer's habitual residence to the extent that it is more favorable than the chosen

\footnotetext{
${ }^{80}$ See also Washington Mutual Bank v. Superior Court, 24 Cal.4 ${ }^{\text {th }} 906,103$ Cal.Rptr.2d 320, 15 P.3d 1071 (Cal. 2001).

${ }^{81} 2000$ WL 1909373 (E.D.Pa. 2000).

${ }^{82}$ Kansas Statutes $\S 50-627$ (b) (1).
} 
law. Read literally Article 5, thus, calls for application of a law mix based on a comparison of the substantive results attained under the law chosen by the parties on the one hand and the law of the consumer's habitual residence on the other. ${ }^{83}$ A closer look, however, reveals that the workings of the two concepts in practice is actually very similar: On the one hand, in Europe courts hardly ever engage in the comparison of the chosen law and the law of the consumer's habitual residence required by Article 5. Instead, they either consider the mandatory provisions of the consumer's country as being applicable in spite of the parties' choice of a foreign law or apply the law of the habitual residence to the entire contract. $^{84}$ On the other hand, under the American fundamental public policy doctrine the choice-of-law clause is only invalid if it goes against a state's fundamental public policy. This is only the case if the chosen law affords less protection to the consumer than that state's law. If it affords greater protection there is no violation of public policy and the choice-of-law clause will be enforced. Just like under the Rome Convention it is, therefore, the law more favorable to the consumer that will usually prevail.

The finding of transatlantic convergence is also supported by

\footnotetext{
${ }^{83}$ Jürgen Basedow, Internationales Verbrauchervertragsrecht - Erfahrungen, Prinzipien und Europäische Reform, in FESTSCHRIFT FÜR ERIK JAYME, VOLUME I 3, 15-16 (Heinz-Peter Mansel et al. eds., 2004) [hereinafter Basedow, Internationales Verbrauchervertragsrecht]; Jürgen Basedow, Consumer Contracts and Insurance Contracts in a Future Rom-I Regulation, in ENFORCEMENT OF INTERNATIONAL CONTRACTS IN THE EUROPEAN UNION. COVERGENCE AND DiverGenCe BeTWEen BRUSSEls I AND Rome I 269, 279-280 (J. Meeusen et al. eds., 2004) [hereinafter Basedow, Consumer Contracts and Insurance Contracts in a Future Rom-I Regulation]; DICEY \& MORRIS, supra note 57, no. 33-016, at 1289-1290; Dieter Martiny, Verbraucherverträge, in INTERNATIONALES VERTRAGSRECHT, supra note 33, no. 826, at 684-685. ${ }^{84}$ See, e.g., BGH, Oct. 26, 1993, IPRsPR. 1993, no. 37, 97; Tribunal d'instance Niort, July 1, 1998, CONTRATS, CONCURRENCE, CONSOMMATION 18, no. 137 (1998). See for a detailed account Basedow, Internationales Verbrauchervertragsrecht, supra note 83, at 16-17; Basedow, Consumer Contracts and Insurance Contracts in a Future Rom-I Regulation, supra note 83 , at $279-82$.
} 
recent legislative enactments: Both the Louisiana and the new Oregon choice of law code provide for application of the law at the consumer's habitual residence if his assent to the contract was obtained in that state, or if he was induced to enter into the contract for example by an invitation or advertisement in that state. ${ }^{85}$ Additionally, both the new UCC as well as the UCITA contain special rules for consumer contracts that provide for application of the law most favorable to the consumer: According to the new UCC $\S 1-301$ (e) (2) a free choice of law may not deprive the consumer of the protection of any mandatory rule of law of the state or the country in which he principally resides or-if the transaction is a sale of goods-of the state or country in which he both made the contract and took delivery of those goods, if such state or country is not the state or country in which he principally resides. By the same token, UCITA $\S 109$ (a) provides that a choice of law is not enforceable in a consumer contract to the extent it would vary a rule that may not be varied by agreement under the law of the jurisdiction whose law would apply in the absence of the agreement. Since both provisions are clearly modeled after Article 5 of the Rome Convention, ${ }^{86}$ they prove, again, that American and European law are moving closer. ${ }^{87}$

${ }^{85}$ Louisiana Revised Statutes $\S 51: 1418$ B and C (1); Oregon Revised Statutes $\S 81.105(4)$.

${ }^{86}$ See for the implementing status of the two acts supra note 56.

${ }^{87}$ It needs to be mentioned, however, that Article 5 (1) which served as a model for UCC $\S 1-301$ and UCITA $\S 109$ is currently under discussion. More specifically, Article 5 (1) of the Proposal for a Rom I-Regulation excludes any choice of law in consumer contracts and calls for application of the law of the consumer's habitual residence. It, thus, abandons the very approach that has just been adopted in the United States. However, the draft provision is highly disputed so that - as of 2006 - it is unclear whether it will finally be enacted. Even if it is enacted it is unclear whether it will lead to substantial change in practice: First, it has been mentioned earlier, that European courts under the current regime do not engage in a comparison of substantive laws but tend to apply the law of the consumer's habitual residence to the entire contract. Second, even if a choice of law is completely excluded in consumer contracts terms of a foreign law may still be incorporated by reference. Since incorporation operates within the limits 


\section{ii. Employment Contracts}

Next to consumer contracts the Rome Convention also grants special protection to employees: According to Article 6 (1) a choice of law clause in an employment contract must not deprive the employee of the protection of the mandatory rules of law which would be applicable in the absence of a choice of law, ${ }^{88}$ i.e. the law of the country where the employee habitually carries out his work. A choice-of-law clause in an employment contract, therefore, cannot strip the employee of the protective laws at the place of his employment. The employee may always rely on the mandatory rules of this place and thereby on the law whichever is the more favorable to him.

The Restatement (Second) and the UCC, in contrast, do not provide for any rules designed to protect employees against a choice of law. But does that mean that the parties are really free to choose the applicable law in the United States? At first sight, the answer seems to be yes. There it a great number of cases in which choice-of-law clauses were actually upheld. A closer look, however, reveals that most of these cases revolved around choiceof-law clauses that called for application of the place of employment. ${ }^{89}$ Cases enforcing choice-of-law clauses calling for application of a law other than this place are few and-most

of the freedom of contract the difference between the current and the possible future Article 5 are minor.

${ }^{88}$ The Proposal for a Rome I- Regulation will not bring about any changes in this respect: Article 6 (1) of the Proposal is identical to Article 6 (1) of the Rome Convention.

${ }^{89}$ See, e.g., Pirkey v. Hospital Corporation of America, 483 F.Supp. 770,772-773

(D. Col. 1980); Upshaw v. Equitable Life Assurance Society of the United States, 85 F.R.D. 674, 676 (E.D. Arkansas 1980); Penn-Dixi Industries, Inc. v. PennDixie Steel Corporation 22 B.R. 794, 797 (Bky.S.D.N.Y. 1982). Burbank v. Ford Motor Company, 703 F.2d 865, 866-867 (5 ${ }^{\text {th }}$ Cir. 1983). See also Parets v. Eaton Corporation, 479 F. Supp 512 (E.D. Mich. 1979) (upholding a Michigan choice of law clause on the basis that Michigan was the envisioned place of employment after completion of an assignment abroad). 
importantly-date back to the 1970 s. $^{90}$ Recent cases, in contrast, indicate that American courts tend to invalidate choice-of law clauses in employment contracts under the fundamental public policy exception entailed in Restatement (Second) $\S 187$ (2) (b). ${ }^{91}$ More specifically, American courts tend to invalidate choice-oflaw clauses that call for application of a law other than the law of the place of employment the main argument being that this would usually be the law otherwise applicable under Restatement (Second) $§ 188 .{ }^{92}$ Especially when it comes to non-competition agreements American courts almost always ignore a choice of law if the chosen law violates the employment protection laws of the state where the employee had to perform the contract. ${ }^{93}$ But the domain of the fundamental public policy doctrine extends beyond non-competition agreements. ${ }^{94}$ In fact, it covers almost all contractual rights and duties arising out of employment contracts. In the recent case Wright v. Martek Power, Inc., ${ }^{95}$ for example, an

${ }^{90}$ See, e.g., Matthews v. Swift and Company, 465 F.2d $814\left(5^{\text {th }}\right.$ Cir. 1972); Craig v. Bemis Company, Inc. (5 ${ }^{\text {th }}$ Cir. 1975$)$; Boase v. Lee Rubber \& Tire Corporation, 437 F.2d 527 ( $3^{\text {rd }}$ Cir. 1970).

${ }^{91}$ See also Symeonides, Choice of Law in the American Courts in 2004, supra note 22, at 970: "Because of the likely unequal bargaining power of the parties, choice-of-law clauses in employment contracts usually encounter strict and often fatal judicial scrutiny."

${ }^{92}$ See for cases that applied the law at the place of employment in the absence of a choice-of-law clause Priestman v. Canadian Pacific Ltd. 782 F. Supp. 681 (D.Me. 1992); Ferrofluidics Corporation v. Advanced Vacuum Components, Inc. 789 F.Supp. 1201 (D.N.H. 1992); D'Agostino v. Johnson \& Johnson, Inc. 605 A.2d 252 (N.H.App. 1992); Brazones v. Prothe, 489 N.W. 2d 900 (S.D. 1992), Burnside v. Simpson Paper Company 832 P.2d 537 (Wash. App. 1992).

${ }^{93}$ See, e.g., Boyer v. Piper, Jaffray \& Hopwood, Inc. 391 F.Supp. 471, 472-473

(D.S.D. 1975); Forney Industries, Inc. v. Andre, 246 F.Supp. 333, 334-335

(D.N.D. 1965); DeSantis v. Wackenhut Corporation, 793 S.W.2d 670, 677-681

(Tex. 1990); Nasco, Inc. v. Gimbert, 239 Ga. 675, 676 (1977).

${ }^{94}$ A violation of a state's fundamental public policy is most likely to be found where choice-of-law clauses are excluded by statutes. See, e.g., Florida Statutes $\S 685.101$ (2) (b); Ohio Revised Code $\S 2307.39$.

${ }^{95} 314$ F.Supp. 2d 1065 (U.S.D.C. Colorado 2004). See also Coleman v. Zenodata Corporation, 2004 WL 2202027 (Cal. App.); Davies v. Humble Oil \& Refining Company, 283 So.2d 783, 786-790 (La. Ct. App. 1973). 
employee, a Colorado citizen working in Colorado, brought an action against his former employer, a Delaware corporation with its principle place of business in California, for breach of an implied covenant of good faith and fair dealing. The employer denied this claim pointing to a Texas choice of law in the employment contract and the fact that Texas did not recognize any such implied covenants. The United States District Court for the District of Colorado, however, struck down the choice-of-law clause. It argued that Colorado-the state with the most significant relationship to the dispute-recognized an implied covenant of good faith and fair dealing in all contracts. Since this was an expression of Colorado's interest in protecting the reasonable expectations of the parties to an employment contract, the court held that the application of Texas law would be contrary to a fundamental policy of Colorado. ${ }^{96}$ All in all, it seems, therefore, that-today-in a majority of cases conflicts issues involving employment contracts are subjected to the law of the place of employment. Since this is the rule that prevails in most cases under Article 6 (1) of the Rome Convention, again a striking convergence in results can be observed.

\section{iv. Insurance Contracts}

A final type of contract that is afforded special treatment under both European and American choice of law are insurance contracts. Under both regimes the parties' freedom to choose the applicable law is limited where small business and consumer risks are involved. In Europe, this follows from a complex-and at times inconsistent-interplay of different provisions whose application depend on the type and the location of the risk insured: First, if the contract is for non-life insurance and the risk is located in the European Community Articles 7 and 8 of Directive $88 / 357^{97}$

\footnotetext{
${ }^{96} I d$. at $1067-1068$.

${ }^{97}$ Second Council Directive 88/357/EEC of 22 June 1988 on the coordination of laws, regulations and administrative provisions relating to direct insurance other than life assurance and laying down provisions to facilitate the effective
} 
provide for application of the law at the policyholder's habitual residence. A free choice of law will only be honored in exceptional cases, ${ }^{98}$ most importantly where the law of the policyholder's habitual residence grants party autonomy or where the contract is for the insurance of large risks. ${ }^{99}$ Second, if the contract is for life insurance and the risk is located in the European Community Article 32 of Directive 2002/83 ${ }^{100}$ provides for application of the law at the policyholder's habitual residence. ${ }^{101}$ However, the parties may choose another law if the law at the policyholder's habitual residence allows them to do so or where the policyholder is a natural person that has his or her habitual residence in a member state other than that of which he or she is a national. In the latter case the parties may additionally choose the law of the member state of which the policyholder is a national. Third, if the risk is situated outside the territories of the European Community, $^{102}$ Article 5 of the Rome Convention affords protection to policyholders that qualify as consumers. A free choice of law in accordance with Article 3 is only allowed where Article 5 is not applicable. ${ }^{103}$ The bottom line of this confusing

exercise of freedom to provide services and amending Directive 73/239/EEC, 1988 O.J. (L 172) 1 (as amended).

${ }^{98}$ See Article 7 (b), (c), (d), (e) and (f) of the Directive 88/357/EEC, supra note 97.

${ }^{99}$ This exception does not gain much importance in the context of small business and consumer risks since these are hardly ever classified as large risks. Compare the list of large risks in Article 5 (d) of the First Council Directive 73/239/EEC of 24 July 1973 on the coordination of laws, regulations and administrative provisions relating to the taking-up and pursuit of the business of direct insurance other than life assurance, 1973 O.J. (L 228) 3 (as amended). ${ }^{100}$ Directive 2002/83/EEC of the European Parliament and the Council of 5 November, 2002 concerning life assurance, 2002 O.J. (L 345) 1 (consolidated version).

${ }^{101}$ Article 32 refers to the "law of the member state of the commitment" which is defined in Article $1(1)(\mathrm{g})$ as the law of the member state where the policyholder has his or her habitual residence.

${ }^{102}$ Other risks are excluded from the Rome Convention according to Article 1 (3) because they are covered by the aforementioned Directives.

${ }^{103}$ If the risk is located outside the European Community but the insurer is established within, the national rules of the member states determine the 
conglomerate of provisions is not easy to draw. However, by and large one may say the European regime subjects small business and consumer risks in most cases to the law of the state where the risk is located, i.e. the law of the policyholder's habitual residence. Freedom to choose the applicable law is granted only in exceptional circumstances.

In the United States, the situation of free choice of law in insurance contracts looks rather similar. This holds true even though both the Restatement (Second) and the UCC do not contain provisions specifically with free choice of law in insurance contracts. However, choice-of-law clauses in such contracts are often invalidated by means of the fundamental public policy doctrine previously explored. The commentary to Restatement (Second) § 187 (2) (b) even states that "statutes involving the rights of an individual insured as against an insurance company" are good examples for statutes which embody a fundamental public policy. ${ }^{104}$ And the commentary to Restatement (Second) $§ 193$ goes on: "Effect will frequently not be given to a choice-of-law provision in a contract of fire, surety or casualty insurance which designates a state whose local law gives the insured less protection than he would receive under the otherwise applicable law". ${ }^{105}$ Against this background American courts have long invalidated choice of law clauses in insurance contracts between individuals and insurance companies. They have done so mostly in cases where the choice-of-law clause would have deprived the policyholder of the protection afforded to him under the law of his or her habitual residence because this would be the law otherwise applicable under Restatement (Second) § 193. In Param Petroleum Corporation v. Commerce e) Industry Insurance Co. ${ }^{106}$ for example, the court invalidated a New York choice-of-law clause in an

applicable law. Since the latter case is rather the exception in the context of small business and consumer risks they are not treated in this article.

${ }^{104}$ Restatement (Second) $\S 187, \mathrm{cmt}$. g).

${ }^{105}$ Restatement (Second) $§ 193, \mathrm{cmt}$. e).

${ }^{106} 686$ A.2d. 377 (N.J. App. 1997). 
insurance contract insuring the New Jersey operations of a New Jersey policyholder. The court ignored the choice-of-law clause because it violated the interests of New Jersey, the state where the insured risk was located and whose law would have been applicable in the absence of a choice-of-law clause. The court essentially argued that when dealing with risks located wholly within one state the parties to the insurance contract should not be permitted to negotiate away the protection of that state's law, "protection which is intended for the insured, the insurance company, and for those who may suffer damages as a result of an insured risk ${ }^{\prime \prime}{ }^{107}$ Whether this line of cases means that free choice of law in insurance contracts is rather the exception than the rule in the United States is difficult to tell. But one can definitely say that American policyholders-just like European policyholdersare likely to be afforded the protection of the state of their habitual residence.

\section{The TREND OF CONVERGENCE: AN ECONOMIC EXPLANATION}

The previous discussion has proved that the American and the European concept of party autonomy in international law are not as far apart as commonly assumed. The basic approach is fairly similar and leads to similar practical results. In the following part, I endeavor to explain this finding with the help of economic theory. More specifically, I analyze the main features of the American and European approach to party autonomy under the notion of economic efficiency. I address two basic questions: First, is there an economic rationale for granting free party choice of law? Second, can the limitations of the free party choice of law be justified on economic grounds? However, before going into the details one caveat needs to be made: The following discussion cannot provide a comprehensive account of the economic costs and benefits of party autonomy and its limitations. More

${ }^{107}$ Id. at 381. 
specifically, it cannot account for the fact that the granting and limiting of party autonomy is largely a matter of national-or regional-law and as such subject to strategic interactions within and between states. ${ }^{108}$ The following discussion, therefore, does not account for public choice and interest group considerations ${ }^{109}$ but determines the economic costs and benefits of free choice of law from the perspective of a single benevolent and well-informed global legislator that aims for global welfare. Even though this approach is simplistic, it provides economic insights into the development of contracts conflict during the last years.

\section{A. The Supremacy of Party Autonomy as Victory of EFFICIENCY}

From an economic point of view the supremacy of free choice of law in both Europe and the United States is by no means surprising. In fact, there is general agreement in the economic community that granting the parties the freedom to choose the applicable law is-in principle-an efficient approach to the choice-of-law problem. ${ }^{110}$ The basis for this proposition is that

\footnotetext{
${ }^{108}$ See for a discussion of different "models" that can be applied in the economic analysis of private international law Ralf Michaels, Two Economists, Three Opinions? Economic Models for Private International Law-Cross-Border Torts as Example, in AN ECONOMIC ANALYSIS OF PRIVATE INTERNATIONAL LAW 142 (Jürgen Basedow \& Toshiyuki Kono eds., 2006).

${ }^{109}$ See for a public choice analysis of conflict of laws Erin A. O' Hara, Economics, Public Choice and the Perennial Conflict of Laws, 90 GeO. L. J. 941 (2002) [hereinafter O'Hara, Economics, Public Choice and Conflict of Laws]; Erin A. O'Hara, Opting out of Regulation: A Public Choice Analysis of Contractual Choice of Law, 53 VAND. L. REv. 1551 (2000) [hereinafter O'Hara, Opting out of Regulation]; Ribstein, supra note 40, at 274-281.

${ }^{110}$ See, e.g., Francisco J. Garcimartín Alférez, Regulatory Competition: A Private International Law Approach, 8 EUR. J. L. \& ECON. 251 (1999); Andrew T. Guzman, Choice of Law: New Foundations, 90 GEO. L. J. 883, 913-915 (2002); Horatia Muir Watt, Choice of Law in Integrated and Interconnected Markets: A Matter of Political Economy, 9 Colum. J. Eur. L. 383, 386-387 (2003); Erin A. O'Hara \& Larry E. Ribstein, From Politics to Efficiency in Choice of Law, 67 U. CHI. L. Rev. 1151 (2000) [hereinafter O'Hara \& Ribstein, From Politics to
} 
individuals are assumed to be rational maximizers of their own welfare and have idiosyncratic knowledge about their preferences unavailable to anybody else. Therefore, they do not enter a choiceof-law agreement unless they believe that it will make them better off. The reasons why parties think that they will be better off with a choice of law can be manifold: They might select a foreign law because it is better tailored to their needs than the otherwise applicable law. The chosen law, for example, might have an established body of case law that facilitates interpretation of legal rules and thereby avoids future disputes. Or the parties might just want to select a neutral law different from that of their respective domestic laws. However, no matter what the reasons for the choice are as long as the parties agree on the applicable law and as long the choice does not reduce the welfare of third parties it will lead to Pareto efficiency. ${ }^{111}$ It will foster Kaldor-Hicks efficiency if it does not reduce the welfare of third parties more than it increases the welfare of the parties to the choice-of-law agreement. ${ }^{12}$ All in all, party autonomy and free choice of law, thus, stand on firm economic grounds.

Efficiency in Choice of Law]; Erin A. O'Hara \& Larry E. Ribstein, Conflict of Laws and Choice of Law, in ENCYCLOPEDIA OF LAW \& ECONOMICS, VOlUME 5 631 (Boudewijn Bouckaert \& Gerrit De Geest eds., 2000) [hereinafter O'Hara \& Ribstein, Conflict of Laws and Choice of Law]; Francesco Parisi \& Larry E. Ribstein, Choice of Law, in THE PALgRAVe Dictionary OF LAW \& ECONOMiCs, Volume 1236 (Peter Newman ed. 1998); Ribstein, supra note 40; Ribstein, supra note 27; Hans-Bernd Schäfer \& Katrin Lantermann, Choice of Law from an Economic Perspective, in AN ECONOMIC ANALYSIS OF PRIVATE INTERNATIONAL LAW, supra note 108, at 86; MiCHAEL WHINCOP \& MARY KEYES, POLICY AND PRAGMATISM IN THE CONFLICT OF LAWs 38-42 (2001); Woodward, supra note 51.

${ }^{111}$ See for a critical discussion of the presumption of efficiency of contracts Duncan Kennedy \& Frank Michelman, Are Property and Contract Efficient? 8 HOFSTRA L. REV. 711 (1980).

${ }^{112}$ See for a detailed description of the economic benefits of party autonomy Guzman, supra note 110, at 913-15; O'Hara \& Ribstein, From Politics to Efficiency in Choice of Law, supra note 110, at 1186-187; Ribstein, supra note 40 , at 390-412; Ribstein, supra note 27 , at 247-55. 


\section{B. The Limits to Party Autonomy as EXPREssion OF MARKET FAILURE}

If the dominance of party choice of law in both the United States and Europe can be explained with the help of economic theory the question arises whether the same holds true for its limitations. As a matter of principle, economic theory suggests that free party choice of law should only be limited in cases of market failure. In the following I, therefore, analyze whether the existing limitations in both European and American choice of law can be classified as strategies to secure efficiency where the market in and of itself does not do so. The discussion focuses on two generally recognized sources of market failure, which promise the most fruitful insights in this context: First, externalities and third party effects, and second, opportunistic behavior and information asymmetry.

\section{EXTERNALITIES AND THIRD-PARTY EFFECTS}

The first source of market failure that merits closer analysis here relates to externalities and the presence of negative third party effects. Both occur where the parties to an exchange do not bear all the costs associated with a transaction but impose costs on other parties or the society at large. ${ }^{113}$ In the context of party autonomy costs of this kind may arise where the parties choose a law other than the lex fori. This is because such a choice increases litigation costs since it requires application of legal rules that are unknown to local courts and, therefore, usually more difficult to ascertain and apply. However, the mere fact that a party choice of law increases litigation costs does not mean that the choice produces negative third party effects. In fact, this is only the case if the parties to the choice-of-law agreement do not bear the additional costs involved, i.e. if they do not internalize the additional costs. This, in turn, depends on how the applicable law is determined

\footnotetext{
${ }^{113}$ ROBERT COOTER \& THOMAS UlEN, LAW \& ECONOMICS 44-46 (4 $4^{\text {th }}$ ed. 2004); JEFFREY L. HARRISON, LAW AND ECONOMICS 39-46 (3th 2003); HANS-BERND SCHÄFER \& ClAUS OtT, ECONOMIC ANALYSIS OF CIVIL LAW 95 (2004).
} 
and who has to pay for it. Essentially two systems can be distinguished in this context: According to the first onedominant in England and the United States-the applicable law is considered as a fact that has to be argued and proven by the parties. ${ }^{114}$ Therefore, the parties bear the costs of researching and presenting the applicable legal rules. According to the second model-in place in continental Europe, notably in Germany-the applicable law has to be determined by the courts ex officio. ${ }^{115}$ The parties to the choice-of-law agreement, however, have to pay for the determination of the applicable law as part of the court fees. Under both the Anglo-American and the continental European system the parties, therefore, bear the increased costs of choosing a law other than the lex fori. ${ }^{116}$

For the concept of party autonomy under American and European law this finding has essentially two implications: First of all, it demonstrates that the concept of externalities does not provide a

\footnotetext{
${ }^{114}$ Peter North \& J. J. FAWCetT, Cheshire AND NORTH's Private INTERNATIONAL LAW 99-105 (14 ${ }^{\text {th }}$ ed. 1999); SCOLES, HAY, BORCHERS \& SYMEONIDES, supra note $1, \S 12.15$, at 543-46.

${ }^{115}$ See, e.g., BGH, June 23, 2003, 56 NEUE JURISTISCHE WOCHENSCHRIFT [NJW] 2685, 2686 (2003); BGH, Sept. 19, 2001, 55 NJW 1209 (2002); BGH, Dec. 15, 1986, 41 WERTPAPIERMITTEILUNGEN [WM] 273, 274-75 (1987); BGH, Mar. 30, 1976, 39 NJW 1581, 1583 (1976); BGH, June 23, 1964, 27 NJW 2012 (1964); Reinhard Greger \& Reinhold Geimer, in ZÖLLER, KOMMENTAR ZUR ZIVILPROZESSORDNUNG $§ 293$, no. 1 ( $25^{\text {th }}$ ed. 2005); Peter Hartmann, in ZIVILPROZESSORDNUNG $§ 293$, no. 6 (Adolf Baumbach et al. eds., 63 ${ }^{\text {rd }}$ ed. 2005); Dieter Leipold, in STEIN \& JONAS, KOMMENTAR ZUR ZIVILPROZESSORDNUNG $\S 293$, no. 31 (Reinhard Bork et al. eds., $21^{\text {th }}$ ed. 1997); Hanns Prütting, in MÜNCHENER KOMMENTAR ZUR ZIVILPROZESSORDNUNG $§ 293$, no. 2 and 47 (Gerhard Lüke \& Peter Wax eds., $2^{\text {nd }}$ ed. 2000).

${ }^{116}$ Unfortunately, it seems that court fees in Germany do not mirror the actual costs of determining the applicable law. But even if this is so, economic theory does not suggest a limitation of the parties' freedom to choose. Rather, it suggests a modification of the rules on the reimbursement of courts for the determination of the applicable law. See Giesela Rühl, Die Kosten der Rechtswahlfreiheit: Zur Anwendung ausländischen Rechts durch deutsche Gerichte, 71 RABELSZ (2007) (forthcoming). See also Parisi \& Ribstein, supra note 110 , at 239.
} 
rationale for any of the above discussed limitations. More specifically, it does not provide a rationale for limiting the parties' choice of law in purely domestic cases and for excluding the choice of both unrelated and non-state law: ${ }^{117}$ Since the parties internalize the additional litigation costs associated with the choice of law in these instances there are no negative third party effects that might interfere with the presumed efficiency of choice-of-law clauses. Second, the above finding also suggests that recent judicial and legislative trends in the private international law of contracts can be explained with the help of economic theory. This holds true for the fact that few choice-of-law clauses are actually struck down by the courts for want of a connection to a foreign legal system or for want of a substantial relationship to the chosen law. But it also holds true for the legislative abandonment of the substantial relationship requirement as well as the increasing openness towards the choice of non-state laws on both sides of the Atlantic. Economic theory can even explain that the recognition of non-state law has started with bodies of laws, such as the UNIDROIT Principles, the Principles of European Contracts Law and the Uniform Customs and Practices of the International Chamber of Commerce: All three sets of rules share the virtue of containing a set of written rules sufficiently defined and thus relatively easy to ascertain. Therefore, the increase in litigation costs is moderate. At least it does not substantially differ from the increase associated with the choice of a foreign state law which is permitted under both European and American law. It needs to be stressed, however, that economic theory does not require the non-state body of law to be sufficiently codified: As long as the parties internalize the costs associated with the choice of a non-state body of law-regardless of how indeterminate and imprecise it is-the choice will be efficient.

\footnotetext{
${ }^{117}$ See also Ribstein, supra note 40, at 263 (arguing for the choice of an unrelated law); Gerhard Wagner, The Virtues of Diversity in European Private Law, in Jan Smits (ed.), The Need for a European Contract Law 3, 14-15 (2005) (arguing for free choice of law in domestic cases).
} 


\section{OPPORTUNISTIC BEHAVIOR AND INFORMATION ASYMMETRY}

The second source of market failure that promises helpful insights into the limitations of party autonomy under American and European law revolves around opportunistic behavior. Such behavior occurs where one party to a contract takes advantage of his superior knowledge, in order to further his interests, by failing to disclose such information to the other party. ${ }^{118}$ In the context of choice of law this kind of behavior may be found where one party knows more about the applicable law than the other. This is often the case in consumer, employment and insurance contracts: Since the consumer's, employee's or policyholder's contracting partners engage in the same kind of transaction on a day-to-day basis they have a cost-justified incentive to learn the content of alternative laws and to select the law that is most congenial to their interests. The occasionally contracting consumer, employee or policyholder, in contrast, faces severe informational costs and, therefore, often foregoes the acquisition of valuable information. ${ }^{119}$ Under certain circumstances, namely where the consumer, the employer or the policyholders are not able to distinguish different quality levels $e x$ ante, most importantly the level of protection offered under the chosen law, this might lead to a race to the bottom, i.e. the choice of the law with the lowest level of protection. In the worst case, this downward development leads to a market for lemons, i.e. a market for inefficient choice-of-law clauses which might induce a complete break-down of the market. ${ }^{120}$

Some economists have argued that such a downward development is not likely going to take place in consumer and insurance

\footnotetext{
${ }^{118}$ COOTER \& Ulen, supra note 113 , at 47-48; HARRISON, supra note 113 ; SCHÄFER \& OTT, supra note 113, at 94.

${ }^{119}$ See also Wulf-Henning Roth, Grundfragen im künftigen internationalen Verbrauchervertragsrecht der Gemeinschaft, in Privatrecht in Europa - Vielfalt, Kollision, Kooperation 591, 607-611 (Michael Coester et al. eds., (2004).

${ }^{120}$ See George Akerlof, The Market for Lemons: Quality Uncertainty and the Market Mechanism, 84 QUART. J. ECON. 488 (1970).
} 
markets. ${ }^{121}$ Firms would not risk their reputation by choosing a law that decreased the other parties' legal position. Consumers, employees, and policyholders had cheap access to many sources of consumer-oriented information about firms including third-party rating services, magazines and the internet. Therefore, they could confine their dealings to reputable merchants or demand significant discounts when dealing with merchants who lacked a strong reputation. However, these arguments do not hold true for all kinds of transactions and markets because they are based on strong assumptions about firm and individual behavior. For example, they assume that consumers, employees and policyholders can determine the quality level of different laws before contract formation. This, however, does not necessarily hold true especially in regard to the applicable law. By the same token, the arguments assume the consumer's, employee's and policyholder's willingness to invest in the gathering of information about the contracting party and the applicable law. Yet, this assumption depends on whether the expected gains from doing so outweigh the costs involved in the information gathering process. In most transactions the latter will by far exceed the expected gains and thus make the rational consumer abstain from any investigation into the content of the applicable law. ${ }^{122}$ More important, however, is that the above arguments cannot strike with full force under the special conditions of international transactions: First, a company engaging in cross-border sales is a lot less likely to lose or to develop a reputation than a company engaging in one country only. The potential customers are too

\footnotetext{
${ }^{121}$ Parisi \& Ribstein, supra note 110 , at 239-40; Ribstein, supra note 27, at 40911. See also Harvey S. Perlman, Products Liability Reform in Congress: An Issue of Federalism, 48 OHIO ST. L. J. 503, 508-509 (1987) (arguing for free choice of law in product liability cases).

${ }^{122}$ See also Michael I. Krauss, Product Liability and Game Theory: One more Trip to the Choice-of-Law Well, 2002 B.Y.U. L. Rev. 759, 811 and Gary T. Schwartz, Considering the Proper Federal Role in American Tort Law, 38 ARIZ. L. REV. 917, 938-41 (1996) (both arguing that for reasons of asymmetric information a free choice of law in product liability cases will rather provoke a "race to the bottom" than a "race to the top").
} 
dispersed to interact and to exchange information about the firm's performance. Additionally, consumer associations are less organized on an international level and thus less effective in exercising their monitoring function. The firm, therefore, does not run a major risk when submitting the contract to the law of state that shifts as many risks to the consumer, employee, or policyholder as possible. For the same reason it is more difficult for firms to build up reputation that might induce the other party to pay a higher price for the same product but a better law.

Against this background, limitations on party autonomy in respect to consumer, employment and insurance contracts can be rationalized with the concepts of opportunistic behavior and information asymmetry. But the usefulness of the two concepts goes even further: They provide some economic underpinning for the application of the law of the consumer's or policyholder's habitual residence and the employee's place of work. Two facts support this view. First, the informational asymmetry between consumers, employees and policyholders on the one hand and professionals on the other hand is a lot less severe if the law of the consumer's or policyholder's habitual residence or the employee's place of work applies. Consumers, employees and policyholders know the laws at their habitual residence or place of work better than any foreign law. At least they have easier and less costly access to the related information which, in turn, decreases the extent of information asymmetry and increases the chances of an informed decision to contract. Second, and more importantly, professionals can account for different legal rules and shoulder the associated information costs much better than consumers, policyholders or employees. Since they are likely to engage in numerous transactions of the same kind they can gather information about the applicable law more cheaply and apportion the costs to a large number of contracts. In short: Compared to consumers, policyholders and employees, professionals are the 
cheapest cost-avoider. ${ }^{123}$ The risk of opportunistic behavior and information asymmetry, therefore, can explain both the fact that American and European law limit party autonomy in consumer, employment and insurance contracts and the fact that they favor application of the law at the consumer's or policyholder's habitual residence and the employee's place of work.

In contrast, the two concepts cannot be invoked to explain other limitations on party autonomy. This is because in transactions between commercial entities the parties are usually in a position to obtain the relevant information or to bargain for a lower price. As a result, there is no reason to limit choice of law in purely domestic transactions as does Article 3 (3) of the Rome Convention and Restatement (Second) $§ 187 .{ }^{124}$ Just as well, there is no economic reason to limit party autonomy to the choice of a related or connected law. The most recent developments in the field, most importantly the case law lowering the requirements for a connection to a foreign jurisdiction or the chosen law just as well as the most recent legislative enactments in the United States, support this finding.

\section{SUMMARY AND CONCLUSION}

The principle of party autonomy is a popular topic in the private international law of contracts. It has been the focus of numerous law review articles both in Europe and the United States. With the foregoing article I have made two contributions to the field: first, I have demonstrated that American and European conflicts law have moved closer over the last couple of years when it comes to the granting and the design of party autonomy. More specifically, I have argued that American and European law do not only allow parties to choose the applicable law but also restrict the freedom of choice in the same situations and in similar ways. Second, I

\footnotetext{
${ }^{123}$ See also Roth, supra note 119, 607-611 (2004).

${ }^{124}$ See also Wagner, supra note 117 , at 14-15.
} 
have illustrated that the trend of convergence in the context of party autonomy can be explained with the help of economic theory. I have reasoned that the principle of party autonomy is an efficient approach in the private international law of contracts and that limitations to party autonomy, especially those in consumer, insurance and employment contracts can be explained with the presence of market failure, most importantly opportunistic behavior and information asymmetry. On the other hand, I have demonstrated that other limitations to party autonomy, such as the limitation of the parties' choice to state laws and related laws, have no apparent economic underpinning, and that their recentor soon to be expected-abandonment finds support in economic theory.

Of course, this contribution could not provide more than a first insight into the comparative and economic analysis of party autonomy. Further research will be necessary to fully understand the trend of convergence as well as its relation to economic theory. More specifically, further research will be required to determine "why" and "how" American and European law are moving closer and whether this development is actually desirable. With this article I just hope to have shown that comparative analysis and economic theory-as well as the combination of the two-can improve and broaden our understanding of private international law. At the same time I hope to have contributed a small piece to the emerging debate on the Law \& Economics of choice of law-a debate which has only recently gained momentum but which promises fruitful insights into the field that has been shaped by Arthur von Mehren during the last half century. 